ks. Józef Niewiadomski

Wydziat Teologiczny Uniwersytetu w Innsbrucku

DOI: 10.15290/std.2015.01.11

\title{
ECCE HOMO! - DRAMATYCZNE PODEJŚCIE DO PRAWDY O CZŁOWIEKU. INNSBRUCKA TEOLOGIA DRAMATYCZNA W OBLICZU POTRZEB I WYZWAŃ WSPÓŁCZESNOŚCI
}

\section{ECCE HOMO: DRAMATIC APPROACH TO THE TRUTH ABOUT MAN. INNSBRUCK DRAMATIC THEOLOGY FACING THE NEEDS AND CHALLENGES OF THE PRESENT}

Pilate's words "Behold the man" are a good starting point for the dramatic dispute about the truth of humankind. In no way does beholding the tortured victim elicit compassion; rather it increases the mob's lust for persecution. Although Jesus' persecution is akin to the persecution of countless scapegoats throughout human history, his dying is unique. He is in a radical way nonviolent in his dying and free from any wish for revenge. Thus, Christ dies in an act of solidarity with all victims of human history; still his dying is different from theirs. Therefore this death deconstructs the sacrificial order, founded by the murder of a scapegoat; his death reveals the non violent image of God and the image of a man, who is able to give up himself for others (Proexistenz/ sacricium) The founder of Innsbruck Dramatic Theology, Raymund Schwager, therefore viewed Christ's cross both as a source of new anthropological insights and as a source of life. As a homo perfectus (GS 22) Christ unites himself with all human persons by identifying with all victims of human history and by asking the Father in their place for forgiveness for the perpetrators. These fundamental soteriological positions will be examined in this article for their anthropological consequences. In connection with René Girard's mimetic theory, theological 
anthropology is being anchored in an evolutionary world-view and the classical questions about the creation of humanity by God and about original sin are interpreted in a new light. A mimetic conception of human desire stands at the center of this endeavor. The question of a normative anthropology is approached in the context of Christology and Soteriology and is analyzed in the context of the theme pro-existence/sacrifice. The article reflects the general viability of dramatic categories for present-day theological thinking in the face of an intensifying scapegoat-mentality.

Key words: Raymund Schwager, René Girard, dramatic theology, original sin, cross, redemption, scapegoat, sacrifice, (mimetic) desire, evolution, ciolence.

"Oto człowiek" - powiedział Piłat, wskazując na ubiczowanego i ustrojonego w koronę cierniową Jezusa z Nazaretu (J 19, 5). To właśnie Piłat dał rozkaz biczowania. Zrobił to po dyskusji zakończonej enigmatycznym pytaniem: „Cóż to jest prawda?” (J 18, 38); zakończonej więc ucieczką w sceptycyzm, postawą kapitulującą wobec ostrych konfliktów społecznych. Widok ofiary niewinnie umęczonej prowokuje w rozognionej zgrai bynajmniej nie litość i opamiętanie, lecz pożądanie linczu. Widok ofiary przekreśla jakby ten deiktyczny gest Piłata, gest identyfikujący konkretne indywiduum jako człowieka. Widok człowieka niewinnego nie przerywa procesu ofiarniczego, lecz go wręcz potęguje. Pewny swej racji tłum, przyzwyczajony jest przecież do tego, że prędzej czy później jego ofiary stają się funkcją systemu ofiarniczego. Tracąc swe człowieczeństwo stają się one jego częścią: częścią motłochu ogarniętego szałem mentalności prześladowczej $^{1}$. Oceniając sytuacje prześladowania ofiar powierzchownie, dzisiejsza myśl krytyczna wskazuje na ostre przeciwieństwa istniejące między nimi a sprawcami, próbując $\mathrm{w}$ ten sposób dekonstruować systemy ofiarnicze i ratować człowieczeństwo. Dogłębniej rozpatrując sytuację wiktymizacji, odkrywamy lustrzane odbicia dręczycieli i ofiar, a więc paradoksalną wymianę ról2 ${ }^{2}$ Wymiana ta nie dokonuje się przez świadome akty woli jednostki. Złorzecząc tym, którzy ich prześladują, czy też wołając o pomstę do nieba, przez tę żądzę odwetu i zemsty ofiary przyjmują jakby „pólświadomie” rolę oprawcy,

1 Zracjonalizowaną formę tego feneomenu spotykamy w kontekście pokazowych przewodów sądowych inscenizowanych przez totalitarne systemy, jak nazizm czy stalinizm, zmuszających ofiary do „spektakularnego przyznania się do winy”; akt przyznania przekształca bowiem niewinnie oskarżoną ofiarę w słusznie sądzonego winowajcę, kamufluje więc cały akt prześladowczy.

2 Problem lustrzanego odbicia sprawców i ofiar zaostrza się raptownie na naszych oczach. Potęguje go z jednej strony fenomen terrorystów-samobójców, z drugiej zaś coraz wyraźniejsze ukierunkowanie kultury sądowej w kierunku obrony ofiar, prowadzące do paradoksalnej sytuacji, że wszystkie strony inscenizują się jako ofiary. Por. K. Breitenfellner, Wir Opfer. Warum der Sündenbock unsere Kultur bestimmt, München 2013. 
wtłaczając ich aktualnym katom maski ofiar i ratyfikując tym samym mimowolnie tę odwiecznie już funkcjonującą „kuchnię ofiarniczą”. Mechanizm manipulujący ten żądny linczu tłum zracjonalizował w sposób genialny arcykapłan Kajfasz, wypowiadając jawnie sakralną i zarazem magiczną formułę dominującą mentalność kultur archaicznych przez tysiąclecia: „Byłoby przecież lepiej, gdy jeden człowiek umrze, niż miałby zginąć cały naród" (por. J 11, 49; 18, 14). Kajfasz wypowiedział tę formułę jako arcykapłan, dając do zrozumienia, że również sam Bóg jest funkcją systemu. Bóg, który zdaje się być tak samo żądnym oczyszczającej przemocy jak i tłum, który tę ofiarę prześladuje. Funkcją tegoż to ofiarniczego systemu jest również Piłat, ostentacyjnie demonstrujący swoją neutralność w konflikcie i niewinność w kontekście wiktymizacji (por. Mt 27, 24) - neutralność będącą jednak aktem solidarności z rozjuszonym tłumem, z Kajfaszem i jego Bogiem.

W trakcie wydarzeń Pasji Jezusa pewny swej racji tłum zostaje jednak skonfrontowany z radykalną formą dekonstrukcji mitologicznych praw społeczno-kulturowych i religijnych, redukujących wszystkie indywidua (a więc wszystkich aktorów procesu) włącznie z Bogiem do funkcji systemu ofiarniczego. Prześladowana, umęczona i w końcu też ukrzyżowana ofiara - zwiktymizowana tak samo, jak miliony ofiar prześladowanych w historii ludzkości, zaszeregowana więc w poczet ofiar przemocy tego świata - ta jedna konkretna ofiara zdaje się umierać w sposób unikalny, jakby grając w zupełnie innej sztuce, nakładającej się na widoczny gołym okiem dramat przemocy zmieniającej jego sens. Pisma Nowego Testamentu (szczególnie zaś Ewangelie) przedstawiają tę śmierć jako śmierć ofiary absolutnie niewinnej, umierającej nie tylko w postawie zupełnie wolnej od przemocy i jakichkolwiek żądań odwetu, lecz również w postawie pozbawionej rezygnacji i sceptycyzmu co do możliwości dekonstrukcji wydarzeń. Czyniąc to, Ewangelie dokonują dekonstrukcji wszystkich ludzkich religii i kultur dość skutecznie kamuflujących przemoc, umożliwiających przez to rozwój rodzaju ludzkiego, a tym samym postęp kulturowy tego, co potocznie nazywamy humanizmem. Tego typu dekonstrukcja szokuje, ukazuje bowiem system ofiarniczy - czy wręcz kuchnię ofiarniczą ${ }^{3}-$ nie tylko jako jeden $z$ istotnych elementów cywilizacji, lecz wręcz jako motor hominizacji (i to w kontekście procesów ewolucyjnych, procesów dokonujących się zawsze na koszty innych). Odczytując Pasję Jezusa i jego ukrzyżowanie jako szczyt dekonstrukcji świata opartego na procesach ofiarniczych (przedstawiając więc Krzyż jako źródło wiedzy i oświecenia o procesach cywilizacyjnych, 
a Jezusa jako człowieka radykalnie wolnego od przemocy) René Girard ${ }^{4}$, jak mało który z krytycznych myślicieli XX wieku, sprowokował współczesny świat intelektualny. Jego radykalne tezy podkreślają, że to właśnie kultura biblijna (a w szczególności Ewangelie) zmieniły historię świata, zwracając szczególną uwagę na temat „ofiar przemocy”, umożliwiając im właśnie akty prawdziwej wolności. Artykułując ich los jako los niewinnych „kozłów ofiarnych” (w odróżnieniu od przekonania ich przeciwników), ukazując ich człowieczeństwo, przekreślając przez to domniemaną niewinność ucywilizowanej ludzkości, tezy te są tak radykalne, że polaryzują świat nauki. „Profeta czy geniusz”: oto jest pytanie, z którym borykają się krytycy ${ }^{5}$. Członek Akademii Francuskiej René Girard $^{6}, z$ wykształcenia historyk, zajmujący się literaturoznawstwem, później etologią i historią religii, po raz pierwszy zbulwersował kolegów po fachu swoją krytyczną pracą Prawda powieściowa i kłamstwo romantyczne ${ }^{7}$, wykazując, że marzenie Oświecenia o autonomii człowieka jest formą romantycznej iluzji kultury opartej na obsesyjnym kopiowaniu modeli. Girard zbulwersował po raz drugi swoją książką Sacrum i przemoc ${ }^{8}$, poświęconą w gruncie rzeczy roli religii w procesach ewolucji świata i człowieka. Tenże René Girard zaskakuje świat akademicki po raz trzeci tezą dekonstrukcji religii poprzez Objawienie biblijne9. Tezą tą byli zaskoczeni nawet ci przedstawiciele świata nauki, którzy wpierw

$4 \quad$ Girard opublikował po raz pierwszy te radykalne tezy o dekonstrukcyjnej roli Objawienia, a szczególnie Krzyża w dziele o wymownym tytule: Rzeczy ukryte od założenia świata (Des choses cachées depuis la fondation du monde, Paris 1978; po polsku ukazały się jedynie fragmenty z tego dzieła w różnych czasopismach; por.: R. Girard, Rzeczy ukryte od założenia świata, „Literatura na świecie” 12 (149) 1983, s. 74-182; Demaskacja przemocy w ewangelicznym opisie Męki, „W drodze” 1985, nr 4; Logos Heraklita i Logos Jana, „Studia Filozoficzne” 1988, nr 10; Rzeczy ukryte od założenia świata. Geneza kultury i instytucji, „Rocznik Antropologii Historii” 2013. Girard rozwinął systematycznie swoją hermeneutykę religii w: Je vois Satan tomber comme l'éclair, Paris 1999; Widziałem szatana spadającego z nieba jak blyskawica, Warszawa 2002.

5 W Polsce: M. Grabowski, René Girard - antropolog czy profeta?, „W drodze” 1990, nr 12; krótki przegląd krytycznych głosów (w Polsce) prezentuje A. Urbańska-Szymoszyn, Mimesis $i$ przemoc u podstaw girardowskiej teorii kształtowania się zjawisk kulturowo-społecznych, „Rocznik Antropologii Historii. Genealogie kultury” 2013, III, 2(5), s. 512-57.

6 Krótkie informacje biograficzne i dane dotyczące recepcji myśli Girarda w świecie współczesnej nauki w: J. Niewiadomski, Fenomen Girarda, „Roczniki Kulturoznawcze” 2013, t. 4, nr 2 .

7 Idem, Mensonge romantique et véritéromanesque, Paris 1961; po polsku: Prawdapowieściowa $i$ kłamstwo romantyczne, Warszawa 2001.

$8 \quad$ Idem, La violence et le sacré, Paris 1972, po polsku: Sacrum i przemoc, Poznań 1993/94.

9 Girard zreferował główne tezy w jednym z wywiadów już w roku 1973 - publikacja tego wywiadu nie odbiła się jednak większym echem: Discussion avec René Girard, „Esprit”, Nov. 1973, s. 551-558. 
zafascynowani byli myślą Girarda, dopatrując się w niej radykalnej redukcji prawdy o religii do prawdy antropologicznej, widząc w nim tylko i wyłącznie ostrego krytyka religii i adwokata humanizmu, przedstawiającego transcendencję jako fenomen koniecznego do przeżycia oślepienia i pożyteczną iluzję, $z$ której oświecone kultury współczesności mogą bez problemu zrezygnować ${ }^{10}$. Zaskoczeni zostali oni przeciwstawieniem kultury mitu i Objawienia ${ }^{11}$, przeciwstawieniem dekonstrującym mit, mówiącym jasno i otwarcie o odkrywaniu prawd antropologicznych właśnie w kontekście pism biblijnych, zwłaszcza w kontekście Pasji Jezusa.

Zaskoczony był także o. Raymund Schwager, szwajcarski jezuita, powołany w roku 1977 na katedrę dogmatyki w Innsbrucku ${ }^{12}$. Zafascynowany od kilku lat myślą Girarda Schwager dopiero co zakończył swoje dzieło Czy potrzebujemy kozta ofiarnego? ${ }^{13}$, przedstawiające historię Objawienia biblijnego w świetle teorii Girarda, interpretującego pisma Starego Testamentu jako exodus ze świata religii opartej na obrazie Boga pełnego przemocy i przedstawiającego krzyż i los Chrystusa jako los „koniecznego kozła ofiarnego”, zaszeregowanego wprawdzie w poczet ofiar ludzkości, wyróżniającego się jednak nie tylko dlatego, że jego los dekonstruuje mitologiczne przesłania (jak to mówi sam Girard, dla którego krzyż jest źródłem wiedzy, ukazującej prawdziwe człowieczeństwo), lecz przede wszystkim dlatego, że los ten jest źródłem życia ${ }^{14}$, umożliwiającym

$10 \quad$ Jako wymowny przykład por.: S. Simonse, À la recherche des derniers rois boucs emissaries, w: Le Cahiers de l'Herne: René Girard, M. R. Anspach (red.), Paris 2008, s. 98-104, s. 99: „Do czasu publikacji «Rzeczy ukrytych...» w roku 1978 oceniałem Girarda jako współbrata na drodze sekularyzacji niosącego światło Oświecenia w ciemne regiony ofiarnictwa sakralnego" (moje tlumaczenie).

11 Por. J. Bolewski, Mit i prawda kultury. Z inspiracji René Girarda, Warszawa 2007.

12 Pierwsze informacje co do osoby Schwagera i jego teologii w: J. Niewiadomski, Fenomen Girarda, „Roczniki Kulturoznawcze” 2013, t. 4, nr 2, s. 16-18; St. Budzik, Teologia dramatyczna Raymunda Szwagera, w: R. Schwager, Grzech pierworodny i dramat zbawienia w kontekście ewolucji, inżynierii genetycznej i Apokalipsy, Tarnów 2002, s. 7-43; najbardziej obszerne informacje dotyczące biografii i początków teologii Raymunda Schwagera, jak również jego powiązań z Girardem oferuje Mathias Moosbrugger, Die Rehabilierung des Opfers. Zum Dialog zwischen René Girard und Raymund Schwager um die Angemessenheit der Rede vom Opfer im christlichen Kontext, Innsbruck 2014.

13 R. Schwager, Brauchen wir einen Sündenbock? Gewalt und Erlösung in den biblischen Schriften, München 1978 [w ramach wydawanej przez autora niniejszego artykułu edycji dzieł zbiorowych Schwagera w wydawnictwie Herder we Fryburgu Bryzgijskim dzieło to ukaże się w tomie $2 \mathrm{w}$ roku 2016].

14 Listem z 29 marca 1978 Schwager zapoczątkował fascynujący dialog z Girardem na temat „Krzyża jako ofiary” i po raz pierwszy pogłębił tezę Girarda, że Krzyż jest źródłem wiedzy o wymiarze laski, mówiąc o tym, że Krzyż jest źródłem życia. Korespondencja ukazała się w kolekcji dzieł zbiorowych Schwagera, por.: R. Schwager, Briefwechsel mit René Girard. Hg. von N. Wandinger und K. Peter, w: Raymund Schwager Gesammelte Schriften, 
człowieczeństwo w kontekście radykalnych konfliktów społecznych, konfliktów o naturze mimetycznej. Dekonstrukcja, jakiej dokonuje Chrystus jako ten „doskonały człowiek”, umożliwia wspólnocie nie tylko przeżycie konfliktu, lecz prawdziwe życie ludzkie, życie godne człowieczeństwa. „Ojcze, przebacz im, bo nie wiedzą, co czynią" (Łk 23, 34): słowa te objawiają człowieczeństwo w wymiarze doskonałym. Jest to bowiem człowieczeństwo nieprzekreślające człowieczeństwa innych, człowieczeństwa przykrytego maskami sprawców, ofiar i rzekomo neutralnych widzów, ale je umożliwiające. Paradoksalnie rzecz biorąc są to jednak słowa będące wyrazem ofiary, ofiary złączonej przecież z tradycją ofiarniczą ludzkości, ale ofiary jednocześnie tę tradycję przemieniającą. To właśnie ze względu na tę „ofiarę”, tę postawę proegzystencji (sacrificium) antropologia chrześcijańska widzi w Chrystusie „człowieka doskonałego”. I to w świetle jego człowieczeństwa (tradycyjnie rzecz wyrażając: $\mathrm{w}$ świetle historii nadprzyrodzonej) odczytuje ona dramatyczną prawdę o człowieku objawiającą się $\mathrm{w}$ historii, historii nie tylko kultury i religii, włącznie też z prehistorią biblijną, lecz także i w historii natury, a więc wizji ewolucyjnego rozwoju świata i człowieka.

Mój artykuł na temat podejścia do prawdy o człowieku, jakie znajdujemy w tzw. innsbruckiej teologii dramatycznej ${ }^{15}$ ma dwie części, powiązane ze sobą na zasadzie zawikłanych hierarchii ${ }^{16}$. Teoria Girarda jest przecież paradygmatycznym przykładem interdyscyplinarnego podejścia, łączącego dyscypliny nauk humanistycznych i społecznych, cybernetyki, a nawet nauk przyrodniczych właśnie na wzór tzw. „zawikłanych hierarchii” ${ }^{17}$. Skupiam się najpierw na interpretacji współczesności i jej wyzwań, interpretacji jaką umożliwia teoria mimetyczna, posługująca się intensywnie założeniem izomorfizmu struktur myślowych, umożliwiających interdyscyplinarne podejścia do różnych kwestii i zadań życia codziennego, tworzenia teorii, czy też postępu technologicznego.

t. 6, Freiburg 2014, s. 129-135; proces dyskusji analizuje J. Niewiadomski, Step-by-Step: On the Way to the Rehabilitation of the Sacrifice in the Correspondence between Raymund Schwager and René Girard, „Contagion” 2014, t. 21, s. 67-73.

15 Zasady programu badawczego przedstawione były w: R. Schwager, J. Niewiadomski u.a., Dramatische Theologie als Forschungsprogramm, ZKTh 118 (1996) s. 317-334; por. też: J. Niewiadomski, R. Siebenrock, Dramatische Theologie, ein Blick in die Forschungslandschaft, ZKTh 132 (2010) s. 385-388. Informacje na: http://www.uibk.ac.at/rgkw/drama/

Hiérarchie enchevetrée, entangled hierarchy, verwickelte Hierarchien: Co do wartości teoriopoznawczych modelu por.: J.-P. Dupuy, Ordres et Désordres. Enquête sur un nouveau paradigme, Paris 1982; co do recepcji modelu w teologii por. R. Schwager, Grzech pierworodny i dramat zbawienia w kontekście ewolucji, inżynierii genetycznej i Apokalipsy, Tarnów 2002, s. 54-56;

17 Por. M.Zambrzycki, Homo Bioelektromimeticus. System pojęć i hipotez modelowych, „Studia Gdańskie" 2013, t. 32, s. 39-55. 
Założenie izomorfizmu struktur myślowych umożliwia pogląd, że poszczególne dziedziny życia i poszczególne dyscypliny nauki są ze sobą powiązane właśnie na zasadzie zawikłanych hierarchii. Posługując się tymi założeniami, służącymi rozwojowi wizji całościowych, teoria mimetyczna zastępuje systematycznie nowoczesną ideę autonomii przez paradygmat obopólnych zależności. W drugiej części szkicuję kilka nowych podejść do tradycyjnych problemów antropologii chrześcijańskiej, umożliwionych właśnie przez teorię mimetyczną, kończąc uwagami o przydatności kategorii dramatycznych do rozwoju teologii naszych czasów.

\section{Prawda o człowieku w świetle teorii mimetycznej}

„Oto człowiek” - koncentrując uwagę teoriopoznawczą na problematyce jakże to dwuznacznej roli ujawniania człowieka w ofierze, ukazując Pasję i krzyż jako źródło poznania prawdy o złudnych, a przecież to koniecznych postawach społecznych w kontekście hominizacji i humanizacji ludzkości, dokonując więc dekonstrukcji mentalności kozła ofiarnego, Girard odkrywa ważną część prawdy antropologicznej. Dekonstruując mentalność kozła ofiarnego, ukazując jej prawdę w kontekście teorii socjologicznych, psychologicznych, a także założeń teorii systemu, teoria Girarda zaostrza sytuację współczesności - może więc być pojęta w kontekście logiki, którą posłużył się Carl Friedrich von Weizsäcker w swojej słynnej tezie o roli nauk przyrodniczych, techniki i technologii w dzisiejszym świecie. Są one jedynie z pozoru neutralne. Będąc produktem „poznania bez miłości” potęgują napięcia i szanse rzeczywistości, umożliwiają więc nowe formy dobra, ale też i nowe - bardziej zradykalizowane - formy zła ${ }^{18}$. Dekonstrukcja mentalności kozła ofiarnego radykalizuje więc i pozycjonuje kulturę wspólczesności na krawędzi Apokalipsy. Prostszą alternatywą być nie może: albo radykalna rezygnacja z procesów wiktymizacji (postawa na pierwszy rzut oka liberalna), albo stopniowe pogrążenie w otchłani radykalnej samozagłady ludzkości. Alternatywa tego typu zdaje się kształtować naszą globalną kulturę ${ }^{19}$. $\mathrm{Z}$ jednej strony żyjemy przecież $\mathrm{w}$ epoce ukształtowanej przez myśl liberalną, odrzucającą procesy ofiarnicze w imię wyzwolenia prawdziwego człowieczeństwa, stawiającą często tradycyjną religię (zwłaszcza chrześcijaństwo) pod pręgierzem, oskarżającą je o deprawowanie człowieczeństwa przez tę właśnie mentalność ofiarniczą. Przypominam klasyczną już formułę Jürgena Habermasa, mówiącą o tym, że normatywnym centrum Oświecenia jest rezygnacja

18 C. F. von Weizsäcker, Die Geschichte der Natur, Göttingen 1992, s. 126.

19 Ostatnie dzieło Girarda zdaje się oddychać tą atmosferą i czerpać z niej inspiracje: R. Girard, Achevé Clausewitz, Paris 2007, tytuł niemieckiego tłumaczenia oddaje wiernie charakter książki: Im Angesicht der Apokalypse - Clausewitz zu Ende denken, Berlin 2014; 
$z$ ofiary (ofiary zrozumiałej także jako postawy oddania: sacrificium) ${ }^{20}$. Przeżywamy dziś rewolucję ofiar wyzwalających się z ich własnych roli, znajdujących rzekomo prawdziwe człowieczeństwo w procesie galopujących dziś procesów emancypacji, zmieniających struktury społeczne i świat polityczny. Z drugiej strony wzrasta paradoksalnie coraz bardziej fascynacja rolą i statusem ofiary. „Cierpię, więc jestem”, formułował Pascal Bruckner ${ }^{21}$. Status ofiary staje się coraz bardziej źródłem finansów i kapitału uznania społecznego. Dzieje się to do tego stopnia, że maska (czy też rola) ofiary zdaje się być już identyczną z tożsamością współczesnego człowieka, tożsamością zdeterminowaną nie tylko przez ofiarnicze megaprocesy, ukazujące człowieka jako ofiarę procesów gospodarczych, konfliktów i wojen, czy też katastrof humanitarnych, lecz również przez codzienną kulturę sądową („,chcesz coś osiągnąć - przedstaw się jako niewinna ofiara"), przez kulturę psychologiczną i psychiatryczną, przez współczesną myśl polityczną, ukazującą terrorystów jako ofiary Zachodu, ofiary liberalizmu, czy też ofiary własnej historii. Tę, jakże to paradoksalną sytuację współczesności można i trzeba opisać kategoriami wypożyczonymi z teorii Girarda, stawiając tezę: we współczesnym świecie status ofiary stał się uprzywilejowanym obiektem pożądania mimetycznego ${ }^{22}$.

Jakie są więc główne antropologiczne założenia teorii Girarda? Koncentrując swą uwagę na człowieku jako istocie „opuszczonej przez instynkty”23, ewolucyjna antropologia Girarda znajduje jej punkt wyjścia nie przy człowieku jako istocie rozumnej, ale przy precyzyjnych analizach ludzkich pragnień i pożądań ${ }^{24}$. Główną siłę napędową ludzkiego zachowania teoria ta lokalizuje w mimetycznej strukturze ludzkiego pożądania. Pozostawiając za sobą Marksa i Freuda, definiuje ona pożądanie właśnie nie jako pożądanie dóbr materialnych, czy też obiektów seksualnych. Definiuje ona pożądanie kategoriami „mimesis przywłaszczenia” i „mimesis rywalizacji”; to właśnie one zdają się kształtować

20 Por. J. Habermas, Die postnationale Konstellation. Politische Essays, Frankfurt a. Main 1998, s. 152.

$21 \quad$ P. Bruckner, Ich leide, also bin ich, Weinheim 1996.

22 Por. J. Niewiadomski, Opfer und Täter zugleich. Die mimetische Struktur des Begehrens und die Ambivalenz der "Zeichen der Zeit”, w: Glaubensverantwortung im Horizont der „Zeichen der Zeit”, Ch. Böttigheimer, F. Bruckmann (red.), Freiburg i. Br. 2012, s. 202-231.

23 Por. A. Gehlen, Der Mensch. Seine Natur und seine Stellung in der Welt, Berlin 1940; Wiebelsheim 2009.

24 Por. A. Romejko, Teoria mimetyczno-ofiarnicza - Wprowadzenie do antropologii René Girarda, „Studia Gdańskie” 2002-2003, t. 15-16, s. 55-64; S. Budzik, Teologia a obraz czlowieka na przyktadzie antropologii René Girarda, w: Obrazy świata w teologii i naukach przyrodniczych, M. Heller, S. Budzik, S. Wszołek (red.), Tarnów 1996. 
wszystkie akty woli i działania ${ }^{25}$. Zaborcze naśladownictwo żywi się dynamiką pragnienia: „chcę posiadać to, co inni posiadają; chcę być tym czymś lub też tym, czym lub kim inni są, obojętnie ile to kosztuje”. To właśnie mimesis tego typu uaktywnia siły popędów i instynktów, nakładając się na nie, lub je nawet niszcząc. Naśladownictwo takie jest głęboko zakorzenione w naturze. To właśnie teoretycy ewolucji wskazują w kontekście teorii mimetycznej (i to na zasadzie izomorficznej struktury ludzkiego myślenia), że wszystkie informacje żywej komórki ciała magazynowane są w wielkiej molekule DNA, a do podstawowych właściwości procesów życiowych należy jej zdolność do tworzenia dokładnych kopii samej siebie. Komórki mogą się rozmnażać, dzielić i produkować takie same komórki pochodne. Z podstawowej zdolności kopiowania rozwija się w końcu nawet zdolność naśladowania, która jest charakterystyczna dla zwierząt stojących najwyżej w ewolucji ${ }^{26}$. To dzięki tej zdolności naśladowania pojawiła się możliwość przekazywania wcześniejszych wydarzeń: najpierw przez zmiany w kodzie genetycznym, a później w kontekście procesów historycznych. Teoria mimetyczna przekreśla więc nowoczesny dogmat ostrego rozdziału między nauką a wolnością, ukazując ich obopólną zależność i wyjaśniając tę zależność przy pomocy hipotezy zawikłanych hierarchii.

Definiując pożądanie kategoriami „mimesis przywłaszczenia” i „mimesis rywalizacji” Girard zwraca szczególną uwagę na fakt, że to właśnie ta struktura pożądania prowadzi w sposób „quasi osmotyczny” do agresji i nieokreślonej przemocy. Niehamowana instynktami rywalizacja staje się główną przyczyną agresji, czyniąc z subjektów mimetycznego pożądania jego ofiary. Takiego typu podejście teoretyczne nadaje na nowo tradycyjnej (przez wielu teologów wysłanej do lamusa) prawdzie o grzechu pierworodnym teoriopoznawczą aktualność. Peter Sloterdijk ocenił teorię mimetyczną jako genialną wersję doktryny o grzechu pierworodnym, przetłumaczoną na język współczesności ${ }^{27}$. Tego typu podejście teoretyczne stawia więc teoretyka nie tylko przed fundamentalnym wyzwaniem wyjaśnienia faktu, że człowiek stał się istotą rozumną, lecz także sformułowania odpowiedzi na fundamentalne pytanie w kontekście ewolucyj-

25 Por. B. Strączek, Chciwość jako forma pragnienia mimetycznego w ujęciu René Girarda, w: Chciwość w życiu publicznym, W. Zuziak, J. Mysona Byrska (red.), Kraków 2013.

J. A. Chmurzyński, Mimesis w świecie zwierząt, w: Mimesis w literaturze, kulturze i sztuce, Z. Mitosek (red.), Warszawa 1992; F. de Waal, Der gute Affe. Der Ursprung von Recht und Unrecht bei Menschen und anderen Tieren, München 1997; Wilde Diplomaten. Versöhnung und Entspannungspolitik bei Affen und Menschen, München 1991.

27 P. Sloterdijk, Erwachen im Reich der Eifersucht-Notiz zu René Girards anthropologiszer Sendung, w: R. Girard, Ich sah den Satan vom Himmel fallen wie einen Blitz. Eine kritische Apologie des Christentums, München, 2002, s. 241-254, tu: s. 250 (polskie tłumaczenie dzieła Girarda: Widziałem szatana spadajaccego z nieba jak blyskawica, Warszawa 2002 jest pozbawione tego posłowia). 
nej wizji świata: Jakie mechanizmy umożliwiły przeżycie ewolucyjnych prymatów, tracących przecież stopniowo instynktowne zahamowania i to w świecie nieznającym jeszcze instytucji kanalizujących przemoc i niezamieszkałym przez istoty rozumne. Girard zwraca uwagę na uniwersalnie rozpowszechnione krwawe rytuały ofiarnicze, wyjaśniając ich genezę przez ten sam mechanizm, który powoduje kryzys, a mianowicie przez pożądanie mimetyczne. Przyczyna kryzysu jest więc też i źródłem rozwiązania; pożądanie z natury mimetycznej $z$ jednej strony dzieli prymatów i ludzi (także współczesnych), z drugiej zaś strony też i ich jednoczy. Nie przez świadome akty pojednania, lecz przez mechanizm kozła ofiarnego. Mechanizm ten kanalizuje w sposób mimetyczny (a więc podświadomy) nieokreśloną przemoc powodującą chaos, wyprowadza ją na zewnątrz danej grupy, generując więc pierwotny porządek wedle prostego schematu: winna ofiara tam - my tu; odpowiedzialna za chaos i agresję ofiara w centrum - my zaś wokół tej ofiary, już ukojeni i oczyszczeni mocą ciągle oczywiście jeszcze nieświadomych projekcji. Wychodząc z założenia „zawikłanych hierarchii" między archeologią, prehistoryczną antropologią, religioznawstwem, literaturoznawstwem, szukających przecież też prawdy o człowieku, a także psychologią społeczną i cybernetyką Girard redukuje w sposób genialny złożoność tez i interpretacji, przedstawiając swą centralną hipotezę dotyczącą sedna religijności kultów pierwotnych, religijności archaicznej i religii pogańskiej ustrukturowanej przez rytuały, mity, zakazy i tabu ${ }^{28}$. Sednem tej religijności jest fałszywa transcendencja zrodzona właśnie przez mechanizmy projekcji zarówno zła i dobra. Przemocą wydalona ofiara jest dla oślepionego agresją tłumu ucieleśnieniem zła, czymś co można by nazwać mysterium tremendum. Jej zabójstwo przynosi tejże to grupie jednak spokój, umożliwiając jej przeżycie. Wydalona ofiara przekształca się więc automatycznie w źródło błogosławieństw, jest jakby mysterium fascinosum, jest dawcą życia. „Ludy nie wymyślają swoich bogów, lecz ubóstwiają swoje ofiary"29. Tak scharakteryzował Girard sedno religijności pogańskiej, zdeterminowanej przez mechanizmy mimetyczno-ofiarnicze, zrodzonej więc z mechanizmu kozła ofiarnego. Tego typu bóstwa są pełne przemocy, żądają ciągle nowych krwawych ofiar, gwarantujących porządek i dających właśnie przez to ich żądanie tym wspólnotom życie. Ponieważ sakralizowana przemoc staje się niewidoczna, transcendencja religii archaicznej podobna jest do pięknego futra. Jego powierzchnia, pełna blasku i znaków luksusu, coś przecież zawsze zakrywa. Futro kultury ofiarniczej ukrywa sprzeczności i napięcia społeczne, umożliwiając przez to wspólnocie życie i przeżycie. To właśnie na tym tle (i to jako jeden z nielicznych wspólczesnych myślicieli)

28 R. Girard, Les origines de la culture, Paris 2004; po polsku: Początki kultury, Kraków 2006.

29 Idem, Widziatem szatana spadajacego z nieba jak blyskawica..., s. 82. 
Girard wskazuje na antropologiczne uzasadnienie prawdy biblijnej. Jej przesłanie dosłownie odwraca na opak to ofiarnicze futro, kamuflujące dotąd przemoc społeczną. Rzeczywiste koszty cywilizacji stają się widoczne. Stary Testament nie ubóstwia przecież i nie kamufluje ofiar, czyniąc z wiktymizowanych ludzi datki przyjemne Bogu. Wręcz przeciwnie: ukazuje ich niewinność i dezaprobatę tego typu aktów przez Boga. Widoczna staje się przez to krew ofiary - cena, którą zapłacił jako kozioł ofiarny zwiktymizowany człowiek. Objawienie w tymże to kontekście nie polega jednak na pokazaniu jakichś abstrakcyjnych prawd o Bogu i człowieku. Jest jakby oświeceniem co do natury samego mechanizmu i konkretną drogą, prowadzącą do zjednoczenia ludzi w nowy sposób. Krytyka proroków znalazła na określenie tej drogi krótką i zwięzłą formułę: zamiast krwawych ofiar i aktów wiktymizacji konieczne jest prawo i sprawiedliwość społeczna. Dlatego też wspólnota na cudzy koszt (a zatem i mechanizm kozła ofiarnego) stają się w historii coraz bardziej niemożliwe - przynajmniej w teorii. Objawienie nie prowadzi bowiem automatycznie do nawrócenia na nowe drogi kultury społecznej, przyczynia się najpierw raczej do wzrostu doświadczeń przemocy. Postawienie pod znakiem zapytania wiktymizacji, jako skutecznej drogi tamującej przemoc nieokreśloną, znajduje więc swoją pierwszą konsekwencję w aktach wiktymizacji proroków. Nie jest to wcale przypadkiem, lecz konsekwencją ukazanej przez nich logiki mechanizmu. Los proroków wysuwa teraz najważniejsze pytanie o inspirację prorocką i o źródło ich siły. Czy tą siłą jest jakieś człowieczeństwo odkryte w opozycji do Boga? Patrząc na dramatyzm całej tej drogi odnajdujemy inną odpowiedź. I odnajdujemy też całkiem nowe ślady Boga. Centrum doświadczenia mocy bóstw pogańskich zdawał się być sam rytuał. Praktyka religijna jest identyczna z socjalizacją rytualną. Prorok doświadcza Boga w kategoriach osobowych: Bóg zwraca się do niego jako do partnera, powołując go, nawiązując z nim związek, często nawet bardzo intymny. W odróżnieniu od logiki bóstw pogańskich Bóg Objawienia zdaje się też stać po stronie wiktymizowanej ofiary, ofiary wołającej o zemstę do Boga, ofiary milczącej, ofiary ufającej, że to właśnie Bóg będzie jej wybawicielem. I dlatego pojawiają się tu teologiczne pytania: Jaki Bóg? Bóg pełen przemocy? Bóg niszczący wrogów, ludzi oczywiście zbestializowanych i niezasługujących na godność bycia człowiekiem? Jak już wspomniałem, bóstwa pełne przemocy, żądające ciągle nowych krwawych ofiar, są wynikiem wiktymizacji. Ich genezą jest sam akt prześladowania i zniszczenia. Są one zupełnie podobne do współczesnych ofiar przemocy (zwłaszcza w wieku dziecięcym), definiujących ich dalsze życie w kategoriach ofiary, identyfikujących wszystkie formy oddania i miłości z aktami wiktymizacji. Ofiary gwałtu stają się gwałcicielami, gwałcicielami właśnie w aktach miłości. Po prostu nie mogą sobie 
inaczej wyobrazić aktów oddania niż w formie gwałtu ${ }^{30}$. Na tym tle staje się jasne, dlaczego pogańskie kosmogonie widzą początek stworzenia w akcie wiktymizacji ofiary, a poczęcie wielu bóstw przedstawiane jest przez mity jako akt gwałcenia dziewicy. Na tle tak rozszyfrowanych mitologii jaśnieje na nowo biblijna koncepcja stworzenia, kładąca przecież nacisk na stworzenie przez słowo przestrzeni społecznej dla człowieka, stworzenie środowiska niewywodzącego się z aktów przemocy lecz właśnie z mocy Boskiego słowa, słowa wskazującego na prawdziwą transcendencję, transcendencję nie zredukowaną do funkcji systemu ofiarniczego. Zrodzona z mimetycznej rywalizacji fałszywa transcendencja jest przecież niczym innym niż zsakralizowaną przemocą. Pierwotne akty sakralizacji generują kategorie czasu i przestrzeni, gwarantując przynależność do danej kultury ofiarniczej - kształtują więc kategorie rozumu, struktury sakralnej racjonalności obecnej jeszcze nie tylko u Piłata, ale i we współczesnej myśli politycznej. Sakralnie zakamuflowana przemoc (czy też archaicznie rzecz ujmując bóstwo sakralne) dzieli grupę na tych, co zasługują na pojęcie człowieka i na tych, którzy są tylko barbarzyńcami, obcymi, stojącymi na uboczu, towarem ofiarniczym godnym do poświęcenia w imię utrzymania stabilności społecznej, czy też współcześnie rzecz ujmując: postępu i jakości życia codziennego.

Jaką wartość poznawczą mają te hipotezy dotyczące archaicznych religii dla analizy naszych czasów i wyzwań współczesności? Dość szeroko przyjęta semantyka określająca globalną współczesność jako kulturę neopogańską nie tylko umożliwia pewne analogie; socjologiczne eksplikacje religii w kontekście teorii systemu, ukazujące integracyjną rolę religii w społeczeństwie zdominowanym przez funkcjonalizm, zdają się jakby wypływać z tej to właśnie logiki, ukazującej Boga jako funkcję systemu ofiarniczego, co też na pierwszy rzut oka zdaje się odpowiadać potrzebom współczesności. Wielu teologów ulega tej pokusie formułowania swoich teologii w kategoriach teorii systemu. Teoria mimetyczna (a także innsbruckie dramatyczne podejście do teologii) idą jednak krok dalej, identyfikując radykalne wyzwanie współczesności na innym miejscu. Jak żadna kultura znanych nam dziejów globalna współczesność rozpętała pożądanie mimetyczne na skalę planetarną, nie rozwijając równocześnie w tak intensywny sposób instytucji kanalizujących rywalizację, agresję i przemoc. Stopniowy zanik granic w kontekście procesów komunikacji - powstanie globalnej wioski - zaostrzyło więc naśladownictwo (pożądanie tego samego statusu, tych samych dóbr, tych samych pozycji). Konflikt między światem Zachodu a światem zdominowanym przez islam jest przecież konfliktem mimetycznego pożądania, podobnie jak i konflikt między Izraelem a Palestyńczykami jest konfliktem

30 Por. J. Niewiadomski, Victimaversus Sacrificium. Ambivalenzen des Opfers aus der Perspektive der Innsbrucker Dramatischen Theologie, „Studia Gdańskie” 2013, t. 32, s. 119-140. 
mimetycznym o status ofiary ${ }^{31}$. Zaostrzenie naśladownictwa potęguje agresję nieokreśloną. Egalitarny świat stał się reaktorem pożądania mimetycznego, reaktorem zazdrości i rywalizacji. Popyt na kozłów ofiarnych pacyfikujących sytuację globalnej współczesności jest więc ogromny. Dlatego też współczesna „kuchnia ofiarnicza”, obsługiwana przez media, jest czynna 24 godziny na dobę. Sytuacja ta stawia radykalne wyzwanie dla zglobalizowanego chrześcijaństwa, a także dla kultury Oświecenia. Odkrywając człowieka w ofierze, wskazując na człowieka w coraz to większej i nieprzeliczonej liczbie współczesnych ofiar, kultura ta rezygnuje w międzyczasie, uciekając się coraz częściej (jak Piłat) do pozycji neutralności skazującej konkretne ofiary konfliktu na wiktymizację. Również ucieczka do pozycji sceptycznej wobec nierozwiązywalnych konfliktów społecznych staje się coraz to modniejsza. Poddając do dyskusji samo pojęcie człowieka (rozszerzając więc granice jego semantyki z jednej strony przez integrację świata zwierzęcego, z drugiej zaś świata sztucznej inteligencji) dzisiejsze dyskursy społeczno-polityczne rzucają naszą doświadczalną rzeczywistość na krawędź wizji apokaliptycznych, to jest wizji samozagłady ludzkości. Proste przywoływanie biblijnej prawdy o człowieku w tymże to kontekście, w kontekście współczesnych megaprocesów ofiarniczych, mobilizuje (co prawda na krótką metę) resztkę uwagi, rozpatrując rzecz globalnie. Trzeba by jednak stwierdzić, że strategia przywoływania prawdy biblijnej prowadzi tylko do zaognienia sytuacji politycznej czy też społecznej na świecie. Dynamika rozpętanego pożądania mimetycznego przekracza nie tylko granice planetarne; coraz wyraźniej przekracza ona granice doświadczalnej rzeczywistości. Jedyna - dla wielu myślicieli realistyczna - alternatywa niwelująca wizje apokaliptyczne odwołuje się do postępu technologicznego, do procesu udoskonalania natury ludzkiej przez inżynierię genetyczną, do samomanipulacji człowieka. Mówiąc językiem dramatycznym jest to wezwanie do objęcia roli Boga w dramacie historii, co w kategoriach teologicznych jest niczym innym jak istotą grzechu.

\section{Teologia dramatyczna wobec wyzwań współczesności}

Dramatyczna droga do prawdy o człowieku bierze pod uwagę, że prawda ta kształtowana jest przez konfliktowe interakcje wielu działających, że jej konkretna forma ulega zmianom, spowodowanym nie tylko przez świadome działanie, lecz także zmianom w wyniku przypadku ${ }^{32}$. Dotyczy to przede

31 Por. Religion erzeugt Gewalt - Einspruch, R. Schwager, J. Niewiadomski (red.), Münster 2003.

32 Stosunek prawdy (także dogmatu) do zmian reflektuje Schwager w swoim niedokończonym dziele o dogmacie i dramatycznej koncepcji historii, por. R. Schwager, Dogma und 
wszystkim struktury historii Zbawienia, przedstawionej w przekazie biblijnym ${ }^{33}$. Dramatyczny charakter dziejów historii i losu każdego człowieka towarzyszy ludzkości od momentu grzechu pierworodnego. Jego teologia naświetla więc główne niuanse prawdy o człowieku ${ }^{34}$. Nakładając okulary teorii mimetycznej, teolog odkrywa najpierw masę paraleli w opowieści prehistorii biblijnej $(\mathrm{Rd} z$ 2-11) $)^{35}$. Grzech zaczyna się tam przecież od zafałszowanego naśladowania Boga, które rodzi rywalizację. Działa ona dalej jako rywalizacja między braćmi i osiąga swój moment kulminacyjny w morderstwie. Siedmiokrotna zemsta wzrasta do siedemdziesięciokrotnej; kulminacją dramatycznego rozwoju jest świat pełen przemocy zdewastowany przez potop. Dynamika rozpoczyna się w sposób prawie niewidoczny. Uwodzicielski głos węża przedstawia Boga jako godnego naśladowania; w rzeczywistości głos ten uosabia perwersyjną formą małpowania Boga, jest wręcz symbolem mimetycznego pożądania (pożądania później przecież to zakazanego w Dekalogu dziesiątym przykazaniem, redukującym całą etykę Dekalogu do ostrzeżenia przed ślepą uliczką, w jaką nas wprowadzi pożądanie choćby osła przynależącego do kogoś innego, nie mówiąc już o jego żonie $)^{36}$. Nakładając okulary teorii mimetycznej, teolog odnajduje też ślady dwuznacznego maskowania prawdy. Adam przedstawia się przecież jako ofiara Ewy, Ewa jako ofiara węża; oboje więc wskazują na jakże to współczesne doświadczenia stawania się ofiarą rozpętanego pożądania mimetycznego. Stwierdzenia tego typu narzucają trudności starej tradycji katolickiej ratującej dobrą naturę człowieka nową szatą. Jeżeli na zasadzie izomorfii struktur myślowych wskazujemy już, że zdolność kopiowania należy do podstawowych właściwości procesów życiowych komórki ciała, a zdolność naśladowania jest charakterystyczna dla zwierząt stojących najwyżej w ewolucji, czyż nie jest więc konieczne przyjęcie, że pożądliwość mimetyczna wraz z jej uaktywnieniem, $z$ jej quasi osmotyczną tendencją do agresji, rywalizacji i przemocy (którą oceniłem jako możliwą nową formą myślenia o grzechu pierworodnym), że to właśnie ta pożądliwość jest identyczna z samym aktem stworzenia człowieka,

dramatische Geschichte, J. Niewiadomski, M. Moosbrugger (red.), Freiburg 2014 (Raymund Schwager Gesammelte Schriften, t. VI).

33 Por. R. Schwager, Heilsdrama, w: J. Niewiadomski (red.), Raymund Schwager Gesammelte Schriften, t. IV, Freiburg 2015.

34 M. Kaznowski, Koncepcja grzechu pierworodnego u Raymunda Schwagera, „Studia Gdańskie” 2012, t. 31; idem, Uwiktani w szczęśliwa winę. Grzech pierworodny w świetle teorii mimetyczno-ofiarniczej René Girarda, Kraków 2014.

35 R. Schwager, Grzech pierworodny $i$ dramat zbawienia w kontekście ewolucji, inżynierii genetycznej i Apokalipsy, Tarnów 2002, s. 59-103.

36 Por. R. Girard, Widziałem szatana spadajacego z nieba jak btyskawica, Warszawa 2002, s. 19-25. 
interpretowanym w kontekście teorii ewolucji? Tradycyjne alternatywy zdają się dzisiaj nie wystarczać, potrzeba więc nowych podejść.

Raymund Schwager wskazał już przed laty ${ }^{37}$ na fakt wyraźnie mniejszej objętości mózgu pierwszych ludzi, którym jednak nie było obce bardzo intensywne życie emocjonalne, czy też poczucie życia, asocjując je z relacją do nieskończonej przyczyny życia. Dla objaśnienia tego założenia Schwager wskazał na ludzi upośledzonych i fakt, że umysłowo upośledzony człowiek prowadzi intensywne życie duchowe ${ }^{38}$. Przyjęcie, że taka świadomość ma zdolność podejmowania decyzji nie sprawia większych trudności. Wolność polega przecież na tym, że istota czerpie swoje życie $z$ siebie samej. Takie ujęcie pasuje bardziej do ewolucyjnego niż do statystycznie pojmowanego świata. Pierwsi ludzie byliby więc powołani do tego, by w intensywnym kontakcie emocjonalnym odpowiedzieć na propozycję bliskiego Boga (który przez swoją obecność ukierunkował ludzkie pożądanie). Przyjęcia tego typu są zgodne z tradycją chrześcijańską, przedstawioną w ostatnich latach przez Sobór Watykański II w konstytucji Gaudium et spes, mówiącej o „profundior et universalior appetitio” człowie$\mathrm{ka}^{39}$, istoty ubogiej przecież $\mathrm{w}$ instynkty. Pojęcia nauk przyrodniczych, takie jak „fulguracja” czy też „emergencja”" prymata ze świata zwierząt, czy też filozoficzne pojęcie "samotranscendencji” (określenie najsławniejszego bodaj innsbrucczyka Karola Rahnera ${ }^{41}$ ), którą to zdolność, istota ta zawdzięcza twórczemu działaniu Boga, mogły doprowadzić do tego, że narodziło się w tych istotach zupełnie nowe uczucie o kolosalnym zasięgu. Te doświadczenia miały spowodować nowego typu zachowanie, nową reakcję ludzi wyrastających ze świata zwierząt. Jak utrzymuje nauka o grzechu pierworodnym już od samego początku dochodziło do reakcji negatywnych. Można więc przypuszczać, że duża emocjonalność prowokowała ostre konflikty i spory, a pozytywne mechanizmy ukształtowane w trakcie ewolucji zwierząt, uaktywniły się (ale tylko w perwersyjnej formie). Takie pozostawanie człowieka w „naturalności” unikającej transcendencji, staje się wobec transcendentnego celu nienaturalne. Nie chodzi tu o jednorazowy upadek, ale o całą serię początkowo niezauważalnych reakcji negatywnych; reakcji potęgujących się, zostawiających więc ślady (także w zapisie kodu genetycznego), prowadzące

37 R. Schwager, Grzech pierworodny i dramat zbawienia..., s. 113-117.

38 Na ten to fakt, wskazał m.in. Jean Vanier, założyciel Wspólnoty Arki.

39 Gaudium et spes 9.

40 Por. K. Lorenz, Die Rückseite des Spiegels. Versuch einer Naturgeschichte des menschlichen Erkennens, München 1983.

41 K. Rahner, Die Christologie innerhalb einer evolutiven Weltanschaung, w: Schriften zur Theologie V, s. 183-221, tu s. 190-195, idem, Die Hominisation als theologische Frage, w: Overage, Das Problem der Hominisation, s. 13-90, tu s. 80-84. 
do quasi osmotyczngo powiązania z pożądaniem mimetycznym, skierowanym na wzorce inne niż te wskazane przez transcendencję żywą. Przy interpretacji mimetycznej nie musimy przyjmować, że wszelkie zło pochodzi od jednego lub dwojga ludzi, którzy dopiero co wyłonili się ze świata zwierząt. Dużo bliższa jest teza, że zło wzmagało się przez działanie licznych ludzi, w różnych kulturach i przez dłuższy czas.

Nakładając okulary teorii mimetycznej, teolog odnajduje jednak nie tylko ślady grzechu, maskowania prawdy, ślady głosów bóstwa będącego funkcją systemu ofiarniczego, lecz także i przede wszystkim odnajdzie on Objawienie Boga prawdziwego, głos Boga zważającego na głos ofiar, umożliwiającego ofiarom artykulację ich losu, objawiającego przez to ich człowieczeństwo. Głos nasilający się w kontekście doświadczeń prześladowanych proroków i objawiający się dość jasno w kontekście doświadczeń Jezusa - jedynego człowieka, który nie uległ pokusie pożądania mimetycznego (porównaj historię kuszenia na pustyni) i projekcjom definiującym jego własną tożsamość przez kategorie ofiary. Paralela Adam-Chrystus wzywa do myślenia: tak jak Adam uległ pokusie i zdefiniował się jako ofiara mimetycznego uwodzenia przez kobietę (ta znowu przez węża), prezentując swoje człowieczeństwo w formie zdeformowanej (mentalność ofiar, których człowieczeństwo jest zdeformowane, ofiar skupionych na sobie, zamkniętych w sobie, ilustruje doskonale klasyczną formułę homo incurcatus in se ipsum), tak Chrystus w kontraście do Adama prezentuje się jako homo perfectus, jako człowiek definiujący się przez relacje. Dzięki wymiarowi Boskiemu Jego Wcielenie (a więc Jego człowieczeństwo) charakteryzuje się relacją do każdego człowieka ${ }^{42}$, relacją konkretyzującą się w sposób dramatyczny w momencie Pasji. Innsbrucka teologia dramatyczna opisuje dramat Jezusa w kategoriach Bosko-ludzkich, formalnie podobnych do logiki religii pogańskich, treściowo jednak tej logice przeciwstawnych. Twierdzenie to dotyczy przede wszystkim pojęcia Boga w odniesieniu już do samego Chrystusa. Nie jest On bowiem ubóstwioną ofiarą przemocy. Umrze On, co prawda tak, jak umierają nieprzeliczone rzesze ludzi będących kozłami ofiarnymi w ich otoczeniu. Jego śmierć na krzyżu nie konstytuuje jednak Jego tożsamości. Jest On bowiem Synem Bożym od chwili poczęcia. A i to poczęcie jest tak odmienne od setek mitów opowiadających o współżyciu pogańskich bóstw z dziewicą ${ }^{43}$. Bóstwa, których tożsamość jest identyczna z przemocą, współżyją gwałcąc słabą kobietę, objawiając swoją tajemnicę, tajemnicę bardzo zakamuflowaną: jesteśmy niczym innym, jak tylko sakralnym ekranem projekcyjnym ludzkiej przemocy. Nic

$42 \quad$ Por. Gaudium et spes 22.

43 Por. J. Niewiadomski, „Allmächtiges Wort vom Himmel”. Religion und Gewalt im Kontext der Theorie von René Girard, „Rocznik Antropologii Historii. Genealogie kultury” 2013, III, 2(5), s. 111-134. 
takiego nie znajdujemy w Ewangelii św. Łukasza. Dialog prowadzony przez anioła i tajemnica Wcielenia dokonana przez Ducha Świętego wskazują na sedno tajemnicy Boga i człowieka, jak też i dialogu między nimi. Tajemnica ta nie ma nic wspólnego z przemocą i gwałtem, nawet tym gwałtem najbardziej zakamuflowanym pojęciami sakralnymi. Bóg Objawienia nigdy człowieka nie wiktymizował i wiktymizować go nigdy nie będzie. Jego własny dialog z człowiekiem nie jest dialogiem ustrukturowanym przez przemoc, lecz przez miłość bezwarunkową. Niuanse tejże to tajemnicy objawi Chrystus słowem i czynem, a także własnym losem. Objawiając Boga jako miłosiernego Ojca, pozwalającego wschodzić słońcu zarówno nad dobrymi jak i nad złymi i zsyłającego deszcz na sprawiedliwych i niesprawiedliwych, Jezus wskazuje najpierw na sedno człowieczeństwa w człowieku: „Bądźcie doskonałymi, jak Ojciec wasz niebieski jest doskonały" (Mt 5, 48). Człowieczeństwo zdaje się tu znaleźć swój normatywny wyraz w rezygnacji z polowania na kozły ofiarne. Kazanie na Górze odbiera nam możliwość przemocy sakralnej, kamuflującej naszą własną przemoc ${ }^{44}$. Chrystusowy obraz Boga przebaczającego bezwarunkowo ukazuje tegoż Boga jako całkowicie wolnego od przemocy. I tu leży sedno problemu dramatycznego podejścia do antropologii: falsyfikacja pytania o przemoc w kontekście obrazu Boga nie rozwiązuje problemu przemocy w kontekście międzyludzkim! ${ }^{45}$ Wręcz przeciwnie. Jak już wyżej wspomniałem, to dopiero przemoc ujęta jako problem czysto antropologiczny nasuwa możliwość kwalifikacji polowania na kozły ofiarne. Dlatego też ludzka reakcja na tego typu dobrą nowinę Ewangelii

44 Tak zwane „Antytezy Kazania na górze” (Mt5, 21-48) wskazują w sposób paradygmatyczny na coś radykalnie innego, coś co umożliwia człowieczeństwo w najlepszym tego słowa znaczeniu. Na pierwszy rzut oka zdają się być absurdem. Cóż daje niwelacja różnicy między tym, który zabił a tym, który opanowany przez gniew i złość tylko bliźniemu złorzeczy? Albo tym, który cudzołoży a tym, który tylko pożąda? Przesuwając soczewkę spojrzenia na problematykę pożądania, Jezus radykalizuje Dekalog, dotykając korzeni agresji, a tym samym i przemocy. Antytezy wskazują na możliwość uniknięcia sytuacji opanowanych przez zazdrość, rywalizacje i pożądanie dokładnie tego, czym są inni, albo też, co oni posiadają. Przezwyciężenie tego destruktywnego wymiaru pożądania mimetycznego tradycja chrześcijańska łączy z logiką rad ewangelicznych i z logiką łaski umożliwiającą tego typu profilaktykę. Jednym z najbardziej zadziwiających paradoksów współczesności jest wzrost zafascynowania buddyzmem posiadającym coś z logiki antytez Kazania na Górze. Z drugiej strony obserwujemy rozpętanie tego typu pożądania na skalę globalną i to do tego stopnia jak żadna kultura przedtem tego nie dokonała. Tradycyjne grzechy główne stały się cnotami życia codziennego, produkującego rywalizację i agresję w coraz to bardziej ostrym wymiarze. Dlatego wzrasta też z dnia na dzień zapotrzebowanie na kozły ofiarne, jak również i pokusa, powołującego się na abstrakcyjne pojęcie praw człowieka, oskarżania chrześcijaństwa o negację człowieczeństwa w człowieku.

45 Por. J. Niewiadomski, Nur ein Sündenbock? Dramatischer Zugang zum Erlösungstod Christi, w: Erlösung auf Golgota? Der Opfertod Jesu im Streit der Interpretationen, M. Striet, J.-H. Tück (red.), Freiburg i. Br. 2012, 83-100. 
potęguje reakcję przemocy. To właśnie Ten, Który przez swoją relację z wolnym od przemocy Bogiem wywołuje kryzys nie tylko religijno-społeczny, lecz również i antropologiczny, zostaje skazany na śmierć w imię Boga ratyfikującego przemoc i polowania na kozły ofiarne. Ukrzyżowany tak samo jak miliony ofiar zwiktymizowanych przez swoich bliźnich, Chrystus umiera inaczej, objawiając jeszcze raz człowieczeństwo w wymiarze doskonałym. Otoczony przez motłoch nie staje się częścią zgrai sprawców, złorzecząc tym, którzy Go wiktymizują, czy też wołając o pomstę do nieba, falsyfikując przez to własny obraz Boga. Jest cały czas w relacji ze swoim Ojcem, z Tym, o którego miłości bezwarunkowej mówił już w Kazaniu na Górze. W taki sposób przekształca On wiktymizację przez trzecich w akt oddania się Temu, który umożliwia Mu Jego tożsamość, nadając wydarzeniu przemocy nową treść (sacrificium). Dlatego też i w sytuacji przemocy frontalnej ratuje się modlitwą, jakże już inną od modlitw ofiar przemocy: „Ojcze, przebacz im bo nie wiedzą, co czynią” (Łk 23, 34). Pośrednictwo tego aktu przebaczenia przez Ojca Niebieskiego ukazuje najgłębiej tajemnicę człowieczeństwa, jest więc jakby tym sednem „człowieka w człowieku”. Jest to nawiązanie pierwszych więzów relacji ze sprawcami, umożliwiających im ich człowieczeństwo. To właśnie w tym kontekście staje się widoczne, że Krzyż nie tylko jest źródłem poznania, lecz też i źródłem życia. Akt ten potęguje się w spotkaniu ze Zmartwychwstałym, przynoszącym to samo pojednanie i ten sam pokój przez przepaść grobu. Zmartwychwstanie objawia nie tylko nową formę cielesności. Dekonstruuje też (i to w sposób radykalny) pojęcie Boga, będącego funkcją systemu ofiarniczego. To właśnie Bóg wskrzeszający Chrystusa, demonstruje wyraźnie, że nie jest Bogiem ani Kajfasza, ani Piłata, ani rozjuszonego tłumu żądnego linczu. Schwager ilustruje tę tezę przez przeciwstawienie przypowieści o przewrotnych rolnikach (Mt 21, 33-41) i roli Ojca Niebieskiego w misterium paschalnym. Ojciec wskrzeszający zabitego Syna nie tylko się nie mści, lecz wydaje wyrok na korzyść sprawców i na korzyść ofiary - wysyła bowiem Tego, Który stał się ofiarą z orędziem pojednania: „Pokój wam”. Fakt Zmartwychwstania dekonstruuje też wizje eschatologiczne z podtekstem ofiarniczym, mówiące o zemście w czasach ostatecznych. Pierwszą osobą, która powstała z martwych jest przecież człowiek, który nie tylko był wolny od przemocy i od żądań zemsty, lecz pełen przebaczenia ${ }^{46}$.

Dekonstrukcja, której dokonuje Chrystus, stawia pod znakiem zapytania alternatywę współczesności: albo radykalna rezygnacja z mentalności kozłów ofiarnych, albo coraz to głębsze zagmatwanie w sytuację samozagłady, w sytuację apokaliptyczną. Alternatywa taka, zaostrzająca naszą współczesność,

46 Por. J. Niewiadomski, Das Opfer-Täter-Verhängnis und die Frage nach dem Letzten Gericht, w: Erben der Gewalt. Zum Umgang mit Unrecht, Leid und Krieg, J. Ernesti, U. Fistll, M. Lintner (red.), Brixen/Bressanone 2015, s. 101-116. 
jest rezultatem poznania bez miłości redukującym wymiar Krzyża do źródła poznania. Krzyż jest jednak źródłem życia, i to nie w sensie mentalności ofiarniczej umożliwiającej tylko przeżycie (teologie interpretujące Krzyż w świetle mentalności prześladowczej Ojca umożliwiają w gruncie rzeczy też tylko „przeżycie", jak to ukazuje masochistyczna i dolorystyczna koncepcja naśladownictwa krzyża). Krzyż jest źródłem życia, ponieważ dekonstrukcja, której dokonał Chrystus przez swoje życie, przez swoją naukę i przez swój los, jest produktem poznania wywodzącego się z miłości, a więc poznania prawdziwego Boga, Który jest przecież miłością bezwarunkową. Poznanie to nie zaostrza napięć, maskując konkretne indywiduum maskami sprawców lub też i ofiar (przekreślającymi swoje i cudze człowieczeństwo), lecz daruje im godność człowieka, godność właśnie w kontekście ślepych uliczek powstałych przez rozpętane pożądanie mimetyczne. Proegzystencja Chrystusa (sacrificium) - ten najbardziej wymowny aspekt doskonałego człowieka - przemienia więc akt wiktymizacji, umożliwiając tym, którzy w Niego wierzą, podobne transformacje procesów społecznych czy wręcz też i ewolucyjnych. Człowiek nie jest więc tylko istotą „opuszczoną przez instynkty”. Jest przede wszystkim istotą o „nieograniczonym pragnieniu”. Sobór Watykański II mówi o profundior et universalior appetitio ${ }^{47}$. Tajemnica Synostwa pozwala Chrystusowi na ukierunkowanie tego pragnienia ku Ojcu i Jego bezwarunkowej miłości: podczas życia i w godzinie śmierci. W Kazaniu na Górze przekazuje On nam w gruncie rzeczy dobrą nowinę o tej możliwości. Jako istota opuszczona przez instynkty, człowiek szuka przecież ukierunkowania własnego pragnienia. Poszukiwanie to nie jest bynajmniej banalne, ma ono także wymiar dramatyczny: jedno i to samo pragnienie przekształca się przecież w przeróżne formy pożądania. To właśnie w tym kontekście odkrywamy na nowo prawdę wypowiedzianą przez Schelera: „Każdy skończony duch wierzy albo w Boga, albo w bożka". Konkretne formy tej dewiacji ludzkiego pragnienia pokazuje dziesiąte przykazanie Dekalogu, mówiące o pożądaniu właśnie tego, co należy do innych, jako źródle agresji i przemocy. Jeżeli człowiek jest najbardziej konfliktowym stworzeniem, to nie dlatego, że opuszczony przez inne instynkty, opanowany został przez instynkt przemocy. Główną przyczyną jego agresji jest fałszywie ukierunkowana dynamika pragnienia, przemieniająca je w mimetyczne pożądania rozdzierające wręcz człowieka, dynamika określana w teologii pojęciem grzechu pierworodnego.

Dramatyczna interpretacja nie jest więc wariantem modelu odwołującego się do szczególnego charakteru historii nadnaturalnej, odłączającej wymiar łaski od historii naturalnej i historii wolności, czyniąc z niej nadbudowę, z której inne dyscypliny bezproblemowo mogą zrezygnować. Wychodząc z założenia 
zawikłanych hierarchii, dramatyczna interpretacja próbuje budować pomosty między dyscyplinami. Według świadectwa Objawienia historia nadnaturalna rozgrywa się w całości w historii naturalnej wszechświata. Nie można przecież zaprzeczyć ufności wiary, że Bóg prowadzi historię posługując się przede wszystkim ludzką wolnością, jak też innymi faktorami świata stworzonego według logiki ewolucji, posługującej się przypadkiem. Teologia nie postuluje działania Boga jako przyczyny drugorzędnej, dodanej do badanej przez nauki przyrodnicze przyczynowości. Transcendentny Bóg pozostaje pierwszą przyczyną, Jego działalność stwórcza i działalność mocą Ducha Świętego posługują się jednak przypadkowymi wydarzeniami, katastrofami i wypadkami (zniszczenie Jerozolimy, zniszczenie świątyni, ale i śmierć proroków i śmierć Jezusa), będącymi wynikiem działania ludzkiej wolności i mechanizmów społecznych. Interpretacja dramatyczna przyjmuje, że droga do celu implikuje niespodziewane i zaskakujące nowe początki i nowe perspektywy. Co to ma za znaczenie w kontekście podtytułu, mówiącego o wyzwaniach i wymogach współczesności? Przestrzeń życia społecznego naszej współczesności kształtowana jest w sposób dramatyczny ${ }^{48}$. Życie to oscyluje między coraz to bardziej fragilną strukturą polityczną a determinizmem mechanizmów, tak więc między logiką rozpętanego pożądania mimetycznego i mechanizmami kozła ofiarnego. Przenoszenie napięć społecznych, obwinianie jednostronne, wręcz demonizowanie grup i jednostek są konfrontowane ze świadomą postawą pojednania i integracji ofiar, postawą charakterystyczną dla chrześcijaństwa stojącego przecież w służbie pojednania. Tak to kształtowana przestrzeń życia społecznego, w której to centralną rolę odgrywa również wspólnota Kościoła, jest przestrzenią integrującą inne doświadczenia człowieka, takie jak kwestia skończoności człowieka, jego seksualności i oczywiście przekształcenia doświadczenia natury (coraz to wyraźniej w postaci inżynierii genetycznej i automanipulacji człowieka). Człowiek: istota poznana? Wizje przyszłości nie dają jednoznacznej odpowiedzi na to pytanie. Jeżeli nie chcemy się poddać euforycznej ekstazie wypływającej z bezgranicznego zaufania naukom i technologiom bez miłości, a także nie poddać się wewnętrznemu zwątpieniu pod wpływem rozmiaru problemów współczesności, musimy żywić nadzieję na Odkupienie ${ }^{49}$. Dopóki dotykamy problemu pożądliwości mimetycznej i złudnych mechanizmów kozła ofiarnego z punktu widzenia czysto ludzkiego, dopóty radykalizujemy tę perspektywę jako perspektywę doświadczalnego zła. Zatrzymujemy się więc w zakresie naszej ludzkiej perspektywy, gubimy się wręcz w świecie sprzeczności i potęgujemy mentalność prześladowczą, często w imię dobra i cnoty. Jest to ślepy

$48 \quad$ Por. R. Schwager, Dogma und dramatische Geschichte. Christologie im Kontext von Judentum, Islam und moderner Marktwirtschaft, w: J. Niewiadomski, M. Moosbrugger (red.) Raymund Schwager Gesammelte Schriften, t. 5, Freiburg i. Br. 2014, 320-350. 
zaułek, w którym gubią się postawy liberalne. Wiara w Odkupienie interpretowana dramatycznym modelem, uwypuklającym dramatyczne dzieje obfitujące w coraz to nowe doświadczenia, głębokie rozczarowania, prowadząca stopniowo do radykalnych transformacji przyjętych, uznanych a zanikających obrazów działalności Boga, wiara ufająca, że Bóg, który już tak wiele razy wzbudził nowe życie na gruzach ludzkich wysiłków, wiara w Odkupienie przez Chrystusa uwalnia nas przede wszystkim od mentalności ostatnich partyzantów, usiłujących ratować co się da, trzymających się kurczowo recept na skuteczne opanowanie niezmiernie trudnej problematyki współczesnego społeczeństwa. Naśladując Jezusa, stawiając na ścisły kontakt z Bogiem wolnym od przemocy, śledząc światowe procesy, stosując zasadę duchowego rozróżnienia i ufając, że wiara sama uruchomi proces, który będzie oddziaływał na świat, przyjmujemy postawę sług wypowiadających tę ważną regułę życiową: zrobiliśmy wszystko co nam kazano, co mogliśmy zrobić, co zrozumieliśmy (por. Łk 17, 10). Reszta w ręku Boga!

Słowa klucze: Raymund Schwager, René Girard, teologia dramatyczna, grzech pierworodny, krzyż, Zbawienie, kozioł ofiarny, ofiara, pożądanie (mimetyczne), ewolucja, przemoc.

\section{Bibliografia:}

1. Bolewski J., Mit i prawda kultury. Z inspiracji René Girarda, Warszawa 2007.

2. Breitenfellner K., Wir Opfer. Warum der Sündenbock unsere Kultur bestimmt, München 2013.

3. Bruckner P., Ich leide, also bin ich, Weinheim 1996.

4. Budzik S., Teologia a obraz cztowieka na przyktadzie antropologii René Girarda, w: Obrazy świata w teologii i naukach przyrodniczych, M. Heller, S. Budzik, S. Wszołek (red.), Tarnów 1996.

5. Budzik S., Teologia dramatyczna Raymunda Szwagera, w: R. Schwager, Grzech pierworodny i dramat zbawienia w kontekście ewolucji, inżynierii genetycznej $i$ Apokalipsy, Tarnów 2002.

6. Chmurzyński J. A., Mimesis w świecie zwierząt, w: Mimesis w literaturze, kulturze i sztuce, Z. Mitosek (red.), Warszawa 1992.

7. Detienne M., Vernant J.-P., La Cuisine du sacrifice en pays grec, Paris 1979.

8. Discussion avec René Girard, „Esprit”, Nov. 1973.

9. Dupuy J.-P., Ordres et Désordres. Enquête sur un nouveau paradigme, Paris 1982.

10. Gehlen A., Der Mensch. Seine Natur und seine Stellung in der Welt, Berlin 1940; Wiebelsheim 2009.

11. Girard R., Achevé Clausewitz, Paris 2007.

12. Girard R., Des choses cachées depuis la fondation du monde, Paris 1978. 
13. Girard R., Demaskacja przemocy w ewangelicznym opisie Męki, „W drodze” 1985, nr 4.

14. Girard R., Im Angesicht der Apokalypse - Clausewitz zu Ende denken, Berlin 2014.

15. Girard R., Je vois Satan tomber comme l'éclair, Paris 1999.

16. Girard R., La violence et le sacré, Paris 1972.

17. Girard R., Les origines de la culture, Paris 2004.

18. Girard R., Logos Heraklita i Logos Jana, „Studia Filozoficzne” 1988, nr 10.

19. Girard R., Mensonge romantique et vérité romanesque, Paris 1961.

20. Girard R., Poczatki kultury, Kraków 2006.

21. Girard R., Prawda powieściowa i kłamstwo romantyczne, Warszawa 2001.

22. Girard R., Rzeczy ukryte od zatożenia świata, „Literatura na świecie” 12 (149) 1983.

23. Girard R., Rzeczy ukryte od założenia świata. Geneza kultury i instytucji, „Rocznik Antropologii Historii” 2013.

24. Girard R., Sacrum i przemoc, Poznań 1993/94.

25. Girard R., Widziatem szatana spadajacego z nieba jak btyskawica, Warszawa 2002.

26. Grabowski M., René Girard - antropolog czy profeta?, „W drodze” 1990, nr 12.

27. Habermas J., Die postnationale Konstellation. Politische Essays, Frankfurt a. Main 1998.

28. Kaznowski M., Koncepcja grzechu pierworodnego u Raymunda Schwagera, „Studia Gdańskie" 2012, t. 31.

29. Kaznowski M., Uwikłani w szczęśliwa winę. Grzech pierworodny w świetle teorii mimetyczno-ofiarniczej René Girarda, Kraków 2014.

30. Lorenz K., Die Rückseite des Spiegels. Versuch einer Naturgeschichte des menschlichen Erkennens, München 1983.

31. Moosbrugger M., Die Rehabilierung des Opfers. Zum Dialog zwischen René Girard und Raymund Schwager um die Angemessenheit der Rede vom Opfer im christlichen Kontext, Innsbruck 2014.

32. Niewiadomski J., „Allmächtiges Wort vom Himmel”. Religion und Gewalt im Kontext der Theorie von René Girard, „Rocznik Antropologii Historii. Genealogie kultury” 2013, III, 2(5).

33. Niewiadomski J., Das Opfer-Täter-Verhängnis und die Frage nach dem Letzten Gericht, w: Erben der Gewalt. Zum Umgang mit Unrecht, Leid und Krieg, J. Ernesti, U. Fistll, M. Lintner (red.), Brixen/Bressanone 2015.

34. Niewiadomski J., Fenomen Girarda, „Roczniki Kulturoznawcze” 2013, t. 4, nr 2.

35. Niewiadomski J., Opfer und Täter zugleich. Die mimetische Struktur des Begehrens und die Ambivalenz der "Zeichen der Zeit”, w: Glaubensverantwortung im Horizont der „Zeichen der Zeit”, Ch. Böttigheimer, F. Bruckmann (red.), Freiburg i. Br. 2012.

36. Niewiadomski J., Nur ein Sündenbock? Dramatischer Zugang zum Erlösungstod Christi, w: Erlösung auf Golgota? Der Opfertod Jesu im Streit der Interpretationen, M. Striet, J.-H. Tück (red.), Freiburg i. Br. 2012.

37. Niewiadomski, J. Step-by-Step: On the Way to the Rehabilitation of the Sacrifice in the Correspondence between Raymund Schwager and René Girard, „Contagion” 2014, t. 21.

38. Niewiadomski J., Victima versus Sacrificium. Ambivalenzen des Opfers aus der Perspektive der Innsbrucker Dramatischen Theologie, „Studia Gdańskie” 2013, tom 32. 
ks. J. Niewiadomski, Ecce homo! - dramatyczne podejście do prawdy o człowieku...

39. Niewiadomski J., Siebenrock R., Dramatische Theologie, ein Blick in die Forschungslandschaft, ZKTh 132 (2010).

40. Rahner K., Die Christologie innerhalb einer evolutiven Weltanschaung, w: Schriftenz ur Theologie $\mathrm{V}$.

41. Rahner K., Die Hominisation als theologische Frage, w: Overage, Das Problem der Hominisation.

42. Religion erzeugt Gewalt - Einspruch, R. Schwager, J. Niewiadomski (red.), Münster 2003.

43. Romejko A., Teoria mimetyczno-ofiarnicza - Wprowadzenie do antropologii René Girarda, „Studia Gdańskie” 2002-2003, t. 15-16.

44. Schwager R., Brauchen wir einen Sündenbock? Gewalt und Erlösung in den biblischen Schriften, München 1978.

45. Schwager R., Briefwechsel mit René Girard. Hg. von N. Wandinger und K. Peter, w: Raymund Schwager Gesammelte Schriften, t. 6, Freiburg 2014.

46. Schwager R., Dogma und dramatische Geschichte, w: J. Niewiadomski, M. Moosbrugger (red.), Raymund Schwager Gesammelte Schriften, t. VI, Freiburg 2014.

47. Schwager R., Grzech pierworodny i dramat zbawienia w kontekście ewolucji, inżynierii genetycznej i Apokalipsy, Tarnów 2002.

48. Schwager R., Heilsdrama, w: J. Niewiadomski (red.), Raymund Schwager Gesammelte Schriften, t. IV, Freiburg 2015.

49. Schwager R., Niewiadomski J. i in., Dramatische Theologie als Forschungsprogramm, ZKTh 118 (1996).

50. Simonse S., À la recherche des derniers rois boucs emissaries, w: Le Cahiers de l'Herne: René Girard, M. R. Anspach (red.), Paris 2008.

51. Sloterdijk P., Erwachen im Reich der Eifersucht- Notiz zu René Girards anthropologiszer Sendung, w: R. Girard, Ich sah den Satan vom Himmel fallen wie einen Blitz. Eine kritische Apologie des Christentums, München, 2002.

52. Sobór Watykański II, Konstytucja duszpasterska o Kościele w świecie wspótczesnym Gaudium et spes.

53. Strączek B., Chciwość jako forma pragnienia mimetycznego w ujęciu René Girarda, w: Chciwość w życiu publicznym, W. Zuziak, J. Mysona Byrska (red.), Kraków 2013.

54. Urbańska-Szymoszyn A., Mimesis i przemoc u podstaw girardowskiej teorii ksztaltowania się zjawisk kulturowo-społecznych, „Rocznik Antropologii Historii. Genealogie kultury" 2013, III, 2(5).

55. Waal F. de, Der gute Affe. Der Ursprung von Recht und Unrecht bei Menschen und anderen Tieren, München 1997.

56. Waal F. de, Wilde Diplomaten. Versöhnung und Entspannungspolitik bei Affen und Menschen, München 1991.

57. Weizsäcker C. F. von, Die Geschichte der Natur, Göttingen 1992.

58. Zambrzycki M., Homo Bioelektromimeticus. System pojęć i hipotez modelowych, „Studia Gdańskie” 2013, t. 32. 